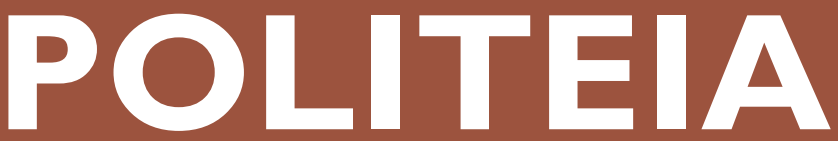

International Interdisciplinary Philosophical Review A non-profit publication

Honorary Board C. Krimpas Academy of Athen

Al. Nehamas Academy of Athens Princeton Univ.

N. Chomsky, M.I.T.

J. Habermas, Univ. of Frankfurt

G. Santas

Univ, of California

Th. Scaltsas
Univ. of Edinburg

N. Pappas
Grad. Stadies Center
CUNY

Phil. Mitsis

New York Univ

J. Humber-
Georgia St. University

I. Vassiliou

Center of Graduate
Studies - CU New York

N. Avgelis

Univ of Thessaloniki

P. Gemptos

D. Anapolitanos

Univ. of Athens

V. Karasmanis
Metsoveion Polytechneion

Ghr. Terezis
Univ. of Patras

G. Apostolopoulou

Univ. of loannina

G. Vassilacopoulos

M. Polemis

Univ. of Klagenfurt

E. Bitsakis

Univ. of loannina

L. Benakis,

of Greek Philosophy

- Academy of Athen

1. Dellis

Univ. of Patras

I. Kucuradi

Univ. of Hacettepe

B. Dziemidok
Univ. of Gdansk

Univ. of Gdansk

(Poland)

Anton Koch
Univ. of Heidelberg

Anna Marbodoro

Kim Nam Duh

Kim Nam Duh

Timothy O' Leary

N. Rescher.

Univ. of Pittsburgh

Darrow Schecter
Univ. of Sussex

Jürgen Stolzenberg

Univ. of Halle

Daimain Zhoug

Nicola Galgano
Univ. of Buenos Aires

\section{CONTENTS}

JANSEN R. - Poetry and Skiagraphia in Republic X: A New Analysis of Tragic Mimesis, 2-27

WU Y. - Philosophy as Memory Theatre: Plato's Odyssey, 28-44

TSALLA H. - Aristotle on Political Norms and Monarchy, 45-67

ALYSANDRATOS I., BALLA D., KONSTANTINIDI D.,

THANASSAS P. - Aristotle's Wondering Children, 68-81

LIU Y. - Creativity Through Lateral Thinking Techniques, 82-87

ANAPOLITANOS D. - Leibniz on Order, 88-98

CHRISTOPOULOU D. - Sets and Necessity, 99-110

CHAKRABORTY S. - The Prospect of 'Hope' in Kant's Philosophy, $111-122$

ANDRIOPOULOS D.Z. - Aesthetic Criterion: A Conceptual Geography, 123-136

ARVANITOPOULOS M. - The Face behind the Fountain: What Heidegger did Not See in Origin, 137-159

\section{Book Review}

PERAKIS E. - N. Avgelis: Introduction to Philosophy \& Philosophy of Language, 160-165

Editorship: D. Z. Andriopoulos, Prof. Emeritus, Philosophical School - Aristotle Univ. of Thessaloniki, P. Dimas, Prof. of Philosophy, Univ. of Oslo (Norway), N. Avgelis, Prof. Emeritus, Philosophical School Aristotle Univ. of Thessaloniki, Phil. Mitsis Prof. of Philosophy, New York Univ. Associate Editors: G. Vassilacopoulos, Prof. of La Trobe Univ. (Australia), An. Marinopoulou, Open Univ. - Greece, Chloe Balla, Univ. of Crete,

Z. Giannopoulos, Univ. of California, F. Peonidis, Prof. of Philosophy - Aristotle Univ. of Thessaloniki Book-Review Editors: An. Marinopoulou, Open University, Chloe Balla, Univ. of Crete, Meredith Drees, Kansas Wesleyan Univ. Assistant Editor: Chr. Grigoriou, Ph.D. Univ. of loannina

Aristotle University of Thessaloniki 


\title{
THE PROSPECT OF 'HOPE' IN KANT'S PHILOSOPHY
}

\author{
Sanjit Chakraborty \\ University of Hyderabad, India
}

\begin{abstract}
This paper discusses Kant's prospect of 'hope' that entangles with interrelated epistemic terms like belief, faith, knowledge, etc. The first part of the paper illustrates the boundary of knowing in the light of a Platonic analysis to highlight the distinction between empiricism and rationalism. Kant's notion of 'transcendent metaphysical knowledge', a path-breaking way to look at the metaphysical thought, can fit with the regulative principle that seems favourable to the experience-centric knowledge. The second part of the paper defines 'hope' as an interwoven part of belief, besides 'hope' as a component of 'happiness' can persuade the future behaviours of the individuals. Revisiting Kant's three categorizations of hopes (eschatological hope, political hope, and hope for the kingdom of ends), the paper traces out Kant's good will as a 'hope' and his conception of humanity.
\end{abstract}

Key words: Kant; Hope; Good Will; Humanity; Summum Bonum; Kingdom of Ends

The question that initiates a debate in philosophy is: Why 'hope' becomes pertinent in Kant's philosophical milieu? Immanuel Kant, a revolutionary philosopher with his 'brilliantlydry style' (in Schopenhauer's sense) constructs philosophy in the fourfold cords upholding the following long debating queries:

a) What is a human being?

b) What can a human know?

c) What a human should act?

d) What may a person hope instead of believe? 
All these questions are interrelated. This paper emphasises 'hope' and analyses its import in Kantian philosophy.

\section{The Boundary of Knowing}

The boundary line that Kant intends to draw, even in the case of knowledge, raises the following questions:

a) What can an agent know about the perceptual world or nature?

b) What can an agent know about the non-perceptual God, the ultimate substance?

In Platonic sense, the perceptual world cannot provide us with true knowledge and the awareness of the world is a kind of animal-like proclivity. But knowledge, as a particular insight of humans, makes a difference with the rest of the animals. Opinion, according to Plato, may present our world relating to the faxable beliefs ${ }^{\mathrm{i}}$, while knowledge makes us conscious of a super sensible external world that hints at the sublime truth. The object of perception seems a particular thing, but the object of intellect (obviously based on reason) concerns an immutable and real universal concept that reflects the idea of good as an ultimate source of all truths and goodness. Russell says, 'Philosophy, for Plato, is a kind of vision, the 'vision of truth'. It is not purely intellectual; it is not merely wisdom, but love of wisdom'

(Russell 1995, 138).

Before Kant, two dominating opinions that govern our European philosophical paradigm are familiar with rationalism and empiricism. The rationalists (Descartes, Spinoza and Leibniz) believe in the reality that has an intrinsic logical structure tested by reasons. Rationalists who believe in Plato's theory of knowledge present that human mind have innate capabilities with certain indubitable ideas. The opponent empiricists (Locke, Berkley, and Hume) put forward a radical opinion that treats experience as the sole source of knowledge and concepts too as opposed to the intuitive knowledge or the superiority of reason-based knowledge that rationalists endorsed.

Kant, who was first motivated by Newton's scientific laws (1766), later realized that metaphysics cannot be suitable for the limited boundary of physics. In Inaugural Dissertation, Selection 2 (1770), Kant follows Christian Wolff's line of thought in defence of the metaphysical crew of thought is authenticated by the indisputable law of contradiction. However, this Wolffian stance later appeared to him as a dogmatic slumber that is broken by the thought of David Hume. Kant himself confesses:

I openly confess that a reminder by David Hume was the very thing which many years ago first interrupted my dogmatic slumber and gave my investigations in the field of speculative philosophy quite a new direction. (Kant, Prolegomena, 159) 
Kant tries to put Hume's quest for empiricism (it means without external reference, reason is unable to provide any insightful knowledge) on the foundation of the concept in association of the causal relation - a necessary connection linking the observed facts to the other- observed and unobserved facts, not filtered through logical reasons and intuitive ideas. As a matter of fact, Kant was dissatisfied with Humean empiricism as he was unwilling to confine himself in the domain of rationalism or empiricism. Kant prefers to consider empirical knowledge with an objective validity (depending on the pure concept of understanding) as judgments of experience, whereas empirical knowledge relates to the subjective validity (depending on logical tie to perception) is called judgments of perception. Kant's critical approach leads him to the transcendental idealism, a sort of Copernican revolution in philosophy. Lewis Beck clarifies:

The content of knowledge, he (Kant) said, comes from experience ( $a$ posteriori); the formal structures and rules lie in the mind a priori, and the content conforms to the structures and rules, not the reverse. (Beck $1988,10)$

One can ask: Why does the 'transcendent' become indispensable here? We know that metaphysics present the conception of reason without basing on experience. If we intend to apply pure reason in the case of experience, metaphysics would be closer to science; besides, if we apply pure reason outside the physical objects, then it goes beyond the scientific assertions. The Critique of Pure Reason (1781) maintains that knowledge seldom transcends experience; yet in part there is an a priori knowledge that is non-conferred from an inductive experience ii $^{\text {. }}$

The initial inquiry of Kant's philosophy outlines the question - what can we know? This seems an epistemic survey within the periphery of metaphysical sphere. Kant emphasizes two faculties of knowledge that he calls sensibility and understanding. Peter Strawson argues:

He distinguishes between the receptive faculty of sensibility, through which we have intuitions, and the active faculty of understanding, which is the source of concepts. (Strawson 1966, 88)

Sensibility is a receiving faculty that copes with the space and time as pure intuitions, while understanding as a thinking faculty captures concepts. So, human reason is based on two interrelated elements of knowledge, namely contents (intuition) and concepts (thought). The possibility of experience remains unfeasible without intuition. The idea that Kant draws here in favour of the transcendent metaphysical knowledge relies on a particular belief that the metaphysical thought could be suitable for the regulative principle beneficial in the pursuit of experience basing on knowledge. 


\section{Beyond the Boundary}

The outline of Critique of Pure Reason is in the nutshell 'thoughts without contents are empty; and intuitions without concepts are blind' (B 75). So, thought needs to be impregnated by the content of thought and there is no alternative way through which concepts can be instantiated in experience without being related to the space and time or in other words our sensibility. However it looks startling when Kant delimits 'belief' by regimenting it from knowledge. The concern 'what can I know?' that we prefer to know subsequently raises the other interesting questions like 'what may I hope?' (Critique of Pure Reason, A 805/ B 833).

Kant appreciates the rational belief, a belief that seems to be the foundational structure of our theoretical and practical knowledge. Beliefs may entertain all manners of things, but 'hope' becomes pertinent since an agent is unable to 'hope' for something only if s/he does not believe in that particular thing. Besides, we can believe in a particular thing without hoping to achieve it. It is true that hope and belief are interwoven in most of the cases, but for Kant, 'hope' always remains attached to happiness or the components of happiness. 'Hope' is a conditional aspiration that cares for something that is ought to happen.

'Hope' is not only a mere belief but a kind of belief that has the power to influence or motivate an individual's behaviour and thought. Kant says that hope is an 'unexpected offering of the prospect of immeasurable good fortune'

We can highlight 'hope' in three different levels, maintaining Kant's thought. These are: Eschatological hope, Political hope, and hopes for the Kingdom of ends.

\section{Eschatological Hope:}

In Critique of Practical Reason, Kant hints at this kind of 'eschatological hope'. The 'eschatological hope' primarily brings about the conception of eternal life, and secondly, it deals with the summum bonum. Actually an eternal life is a kind of justificatory belief where hope takes a privileged stance. Kant concerns about this particular 'hope' since he was worried about the mere cherishment of the natural and moral laws that are only governed by the rational organized world. Kant argues that it may be true that God is not the moral governor of the universe, but the existence of God becomes a necessary condition to establish the model of the summum bonum. Therein lays the challenge when one argues that virtue may not be the cause or the effect of an individual's happiness. So the concept of the summum bonum seems to collapse. Kant's answer would be that we are not bound to do it for the sake of mere 'belief', whereas we must do it for the sake of 'hope'. One can 'hope' for a noumenal world where this necessary condition of the 'hope' turns out as a belief that may be feasible. The belief that aims to support an agent's 'hope' in favour of the summum bonum may induce an agent to assume that God must exist to dispense happiness for the virtuous acts. Critics may argue that the summum bonum thesis, in defence 
of the 'hope' of happiness, dispels the autonomy of virtue by making it an incentive to virtue. It may be better to 'hope' for happiness on the earth instead of the moral happiness in the heaven. Kant's writes,

Happiness, taken by itself, is, for our reason, far from being the complete good. Reason does not approve happiness (however inclination may desire it) except in so far as it is united with worthiness to be happy, that is, with moral conduct. Morality, taken by itself, and with it, the mere worthiness to be happy, is also far from being the complete good. To make the good complete, he who behaves in such a manner as not to be unworthy of happiness must be able to hope that he will participate in happiness. (Kant, $1929,640)$

It needs to be clarified here that Kant aims to discard any kind of superstition, fanaticism or non-moral arguments in defence of the existence of God; according to him morality is a moral law that is nothing but a divine command, an implementation of consecrated duty which His law obligates on us for guiding our morals. So, our eschatological 'hope' looks for a spontaneous moral improvement to achieve an eternal life following the divine command.

Definitely this quest depends on the transcendent world, which seems closer to religion. Still, Kant believes, in the worth of happiness as an issue pertaining to moral conduct since the concept of moral itself cannot be worthy of happiness. Happiness intends to fall within the domain of empiricism (psychological aptitude), while moral thinking relates to human reasoning. Morality is not a mean to getting happiness, but it looks for a rational condition of happiness without entangling the prudence of self-interest. What is a moral wish? Kant thinks that moral wish coupled with the moral laws stimulate the highest good (Kingdom of end) by discarding selfinterest to perform duty for the sake of performing the same.

\section{Political hope:}

Kant likes to engage 'hope' not only in the pursuit of knowledge, but also in the sphere of politics. Metaphysics of politics is a consequence of all that the metaphysics of laws come to. Kant explicitly pursues political concerns in his different periods of writing like What is Enlightenment, Ideal for a Universal History (1774), Perpetual Peace (1795), Metaphysical Elements of Right (1797) etc. His political thoughts are tied up with his moral theories. Kant believes in the concurrence of metaphysics set off that is a sort of a priori principle of reason, which rudimentarily judges the worthy happiness or lawfulness of any political activity.

In An Answer to the Question: 'What is Enlightenment?' (Kant 2009), a well-known work, Kant talks about human's 'self-incurred tutelage', a kind of tutelage where reason is undirected by the resolution and courage. Kant says, 'Have courage to use 
your own reason! - that is the motto of enlightenment' (Kant 1988, VIII. 35). Political progress takes place where the individual has the ability to think about herself where her thought is not directed by any external evil agency. Man needs to be free from the bondage of tutelage (a sort of incapability to utilize a man's own understanding) that nearly becomes her habit. Freedom can help people to attain enlightenment even in the case of politics. Kant puts freedom as an a priori of all rational wills of human beings under which an individual can act. The implementation of the 'good will' of the rational agent is not an individual's self-interested will, rather the overall happiness of the 'good will' entails the overall happiness of the interest of humanity or in other words, performing good for others by 'treating people as ends' in preference to mean. Prejudices from the guardians passed on to their younger generation led towards the reprisal policies that could do harm to our society. Kant defines freedom as follows:

The public use of one's reason must always be free, and it alone can bring about enlightenment among men. The private use of reason, on the other hand, may often be very narrowly restricted without particularly hindering the progress of enlightenment. (Kant 1988, VIII, 36)

Reason as we know for Kant is a social quest that cannot develop in a solitary living individual, but can thrive in the social trail, interface, instructions, etc. people work hard to make the life of next generation much more easy, in a way, they construct future of the next kin. It seems true that human beings have two diverse characteristics that Kant called 'antagonism'. Kant enunciates this in 'Idea for a Universal History':

By 'antagonism' I mean the unsocial sociability of men i.e., there propensity to enter into society, bound with a mutual opposition which constantly threaten to break up the society. Man has an inclination to associate with others, because in society he feels himself to be more than man (i.e., as more than the developed form of his natural capacities). But he also has a strong propensity to isolate himself from others, because he finds in himself at the same time the unsocial characteristic of wishing to have everything go according to his own wish. Thus he expects opposition on all sides because, in knowing himself, he knows that he, on his own part, is inclined to oppose others. (Kant 1988, 417-18)

'Hope', according to Kant is a reasonable rational demand concerning certain contexts. The indispensable connection between the moral laws and 'hope' for happiness is maintained because of 'pure reason'. In our empirical world, there is no assurance of the entanglement of moral laws and 'hope' for happiness; but we can find out this hypothesis only in the case of non-empirical assumptions like highest reason or God. Kant believes in the peaceful future of humanity, especially with political 
progress. He introduces 'hope' in the sense of attaining happiness in near future instead of moral laws. Kant describes 'hope' as being escorted towards happiness; in the same way he argues that the practical necessity to think of moral principles should be interconnected with the theoretical necessity that entails 'hope' where one can get happiness by performing morally-good actions.

What sort of an act should an agent perform in our society? Kant's answer would be recasting a universal framework of natural law that is entangled by a person's good will. One can formulate any maxim for herself and society, but Kant's check point shows that the maxim needs to be followed basing on different outlines:

a) One's maxim must be guided by reason.

b) One should delineate her maxim to shape universal law and its applicability so that other rational agents can universally pursue her maxim in the similar situations.

c) One needs to put her maxim in our conceivable world where natural laws are governed by the society.

d) One should ask himself/herself, whether she would prefer to act according to maxims in this world and if others would follow her maxim in similar situations.

\section{Kant in Groundwork of Metaphysics of Morals claims:}

But if I conceive a categorical imperative, then I know at once what it contains. For since besides the law this imperative, I know at once what it necessity that our maxim should conform to this law, while the law, as we have seen, contains no condition to limit it, there remains nothing over to which the maxim has to conform except the universality of a law as such;... There is therefore only a single categorical imperative and it is this: 'Act only on that maxim through which you can at the same time will that it should become a universal law'. (Kant 1972, 84)

In accepting the moral laws, self-understanding plays a relatable part. It looks inevitable that the summum bonum must be the postulate of moral laws; equally, the existence of God is the foundational claim to attain the summum bonum. Now the query is, 'will it be achieved, at all?' Kant's preference for understanding the power of (reflective) judgment shows self- understanding as a pining requirement of an agent and it signifies nature as it seems classifying along with the lines of intelligent cause (God) that cannot be questioned intelligibly. We have a propensity to prioritize our self-interest and act accordingly. But our actions should be guided by the 'revolution of the will' that can only be explained by two non-fragmented issues:

a) To attain the inscrutable maxim of the moral laws of an agent's behaviour and action depending on 'hope' that intends the person to become a good man through constant efforts. 
b) Without the 'hope' of moral improvement of the human race, no society can reach at its attainment of 'hope' for the better times' as Kant has urged. Actually it is a sort of reasonable 'hope' proliferated through the indispensable presumption of moral duties cum responsibilities for the future generations.

Kant intends to 'hope' for 'better times' that relies on the human motivation and aspiration to act for a common good of society. The social union of mankind calls for a civilized society, but here the problem is we are far from having attained the conception of morality. Hans Reiss writes:

The principles of morality would, in one way, go beyond purely legal questions; for they affect private inner decisions by men which can neither be regulated nor enforced publicly. Law deals only with what remains once such inner decisions have been subtracted. It is the outer shell, so to speak, of the moral realm. And a theory of law is that which can be necessary and universal in the realm of politics. (Reiss 1971, 20)

The affirmative outlook of Kant signifies the principle of public right that synchronies maxims with rights and politics together. The aim of publicizing the motto of public right needs to be accomplished and there should be satisfactory universal public interests emanated from an unconditional imperative sense ensuring happiness.

\section{Kingdom of Ends:}

Kant prefers to look for 'hope' within the realm of religion in his work Religion Within the Boundaries of Reason Alone (1793). As we know, Kant's 'unsocial sociability' hinges at an advance civil state where men can uplift themselves from natural habitats. Human beings become united through the motivation of obeying moral laws to make these a kind of judicial laws of the society. This kind of judicial unity and the community of human beings are called an 'ethical commonwealth' which is not similar to constructing a state, but an individual moral power that relates to the character of the each individual of the society. Beck claries Kant's opinion:

For the establishment of an ethical commonwealth for which man hope's, he feels the need of divine assistance and thinks that, in the foundation of Christianity, he has had it. Consequently belief in God supports the 'hope' of the triumph of good over moral indifferentism and evil in the course of history. The instrument of that triumph will be 'the people of God' united in the 'truth of church'. (Beck 1988, 19)

Kant's optimistic stance focuses on the human's ultimate zeal or endeavour that 
is doubtlessly the idea of 'Highest Good', a complete moral virtue enshrined by the complete happiness. In the preface of the Groundwork of the Metaphysics of Morals, Kant proclaims that nothing can outshine what he calls 'the supreme principle of morality'. The autonomy of 'Good will' is the supreme principle of morality that not only sounds good for Kant in a tautological sense, but especially a will that one can wish and act for the sake of duty. Moral conviction is overtly coupled with the rational will (practical reason) that bring us close to the 'kingdom of ends'. Kant writes:

The concept of every rational being as one who must regard himself as making universal law by all the maxims of his will, and must seek to judge himself and his actions from this point of view, leads to a closely connected and very fruitful concept - namely, that of a kingdom of ends. I understand by a 'kingdom' a systematic union of different rational being under common laws. (Kant 1972, 95)

A rational being can play two different roles in the 'kingdom':

First, as a member of the giving laws, he/she is the subject of the 'kingdom'. Second, a rational being can belong to it as a supreme head. Actually, in the preference of legislating, he/she is not anyway the subject to the will of others.

It's sound puzzling whether a rational being can occupy the place of supreme head i.e. 'God'? Kant believes in two interconnecting policies that can take a man to the sphere of 'supreme head'. The first policy maintains the freedom of the will of the subject (man) even in the case of holding the status of a member or head in the place of 'kingdom'. And the second policy indicates clearly about a complete independent being who have no personal need, but have an inexhaustible power conferred with her will-a kind of will which perform an action depending on maxims that can construct a universal law.

Kant indeed trusts in the individual freedom and aims to segregate it from the domain of theology. We could not make other people moral beings, but it is their own $_{\text {choice }}^{v i}$ not to be guided by coercion to become moral. Morality is generally self-imposed, so there is no question to logically consist of any arbitrary divine command. Even if there is any divine command, then the divine command obviously inspires us to follow 'categorical imperative' that taught us to perform duty for duty's sake. A kingdom of ends creates an ideal condition where people would act following 'categorical imperatives' consistent with rational free will and autonomy of being a subject and supreme head of the laws that she will make and obey in the same manner. Every one in the society will follow the same will. However, this is an ideal picture of a rational and pure reasoned-based society that hardly exists in reality. 'Hope' nourished by Kant in favour of another ground belief is the existence of God as a 
more instantaneous conviction of moral duties. Kant believes in the 'hope' for divine assistance here in performing a moral action, but it is, I think, not in the sense of moral ground as the thesis would be against his dictum; men are free to choose his moral action and they are entirely liable for their good will. In fact, Kant 'hope' for a divine assistance, but the assumption comes from the metaphysical level, never from the domain of the moral laws.

\section{Some words}

My point is that Kant's idea of 'good will' seems infused with 'hope' especially in the result of the particular will. We may be acquainted with the famous Kantian dictum 'It is impossible to conceive anything at all in the world, or even out of it, which can be taken as good without qualification, except a good will' (Kant 1972, 58). Kant was concerned about the fact of rendering 'misfortune' that we may call 'moral luck'. Sometimes, something which is good is incapable to produce its good outcome because of some inevitable misfortunes, but Kant believes that in such a case 'good will' remains still intrinsically good because of its unconditional goodness as a unique feature of any individual 'good'. This 'unconditional goodness' that will always allied with each of good sounds to me close to 'hope' that have some background enabling conditions. 'Hope', as we know, fall under two different schemes. For Kant, a 'hope' is nothing but the primacy of practical reasoning that is the prospect of attaining happiness following the moral acts (categorical imperatives). Besides, the margin of

'hope' is limited in the theoretical level where the consequences are not always fully specified. 'Hope' always draws a weaker contemplation pertaining to the possible notion of knowledge. The epistemic status of 'hope' retains a probability hypothesis, while faith deciphers towards objects of the world in the present sense. But 'hope' transmits to future related matters, or something is relied on one's expectations to desire that might happen.

Adopting this hypothesis, it seems to me that Kant preludes 'humanity as an end' that is a sort of rational choice conferring goodness and rationality. In Metaphysical Principles of Virtue, Kant writes in defence of humanity:

The capacity to propose an end to oneself is the characteristic of humanity (as distinguished from animality). The rational will is therefore bound up with the end of the humanity in our own person, as is also, consequently the duty to deserve well of humanity by means of culture in general, and to acquire or promote the capacity of carrying out all sorts of ends, as far as this capacity is to be found in man. (Kant 1996, 392)

It would not be too ambiguous, if we describe 'humanity as an end' itself a 'hope' that is based on a normative condition to synchronize the rational reason. Irrational 'hope' could escort impossibility, only if the referred object of the particular 
'hope' seems unproven. This is how I understand Kant's constructive part of 'hope' as a subjective reason-centric action that expresses knowledge triggering with a future, which Kant later says in German as Leitfäden or 'come to know'. This epistemic conception of 'hope' cannot be derived from the metaphysical qualm. The ideas for which we should 'hope' like 'summum bonum', 'good will', etc. efficiently stand for the transcendent ideals. There are a lot of places where the conception of one's 'good will' turns out as 'self-prediction', vii , a kind of description rather than a moral decision. 'Good will' is certainly good, but to say that 'good will' would be necessarily 'good' is the root of mutual entailment with others like freedom, happiness, and a panorama of good future (as a pragmatic outcome). This method tends to see 'good will' in an optimistic way that we can call 'hope' in Kantian tune ${ }^{\text {vill }}$.

\section{Notes and References}

i Plato thinks that knowledge form may contrast with the enigmatic physical world as objects have change properties and it can differ according to the sphere of appearance. Reasoning can be the suitable source of knowledge instead of perception that might be the ordinary sources of knowledge. Morton elucidates Plato's theory of knowledge to say, 'Plato suggests tentatively that to know is to believe with a reason for believing. Not any reason will do; it has to be the kind of reason that supports knowledge.' (Papineau 2004, 79)

ii This analysis is impregnated with Russell's thought on Kant's Critique of Pure Reason. Russell also says, 'The part of our knowledge which is a priori embraces, according to him (Kant), not only logic, but much that cannot be included in logic or deduced from it.' (Russell 1995, 679)

iii Please see the work of Kant, Anthropology from a Pragmatic Point of View, 1974, 122. iv See, Kant, Religion Within the Limits of Reason Alone (1793, AE 6:46).

V See Kant's Groundwork of Metaphysics of Morals, 434 or Kant 1972, 95-96.

vi A very interesting definition of choice is depicted by Isaiah Berlin, when he writes, 'Action is choice; choice is free commitment to this or that way of behaving, living, and so on; the possibilities are never fewer than two: to do or not to do; be or not be.' (Berlin 1980, 178)

vii Isaiah Berlin rightly says, 'It seems to me that I can, at times, though perhaps not always, place myself, as it were, at an outside vintage point, and contemplate myself as if I were another human being, and calculate the chances of my sticking to my present resolution with almost the same degree of detachment and reliability as I should have if I were judging the case of someone else with all the impartibility that I could muster. If this is so, then 'I know how I shall act' is not necessarily a statement of decision: it can 
be purely descriptive. Self-prediction of this kind, provided that it does claim to be too exact or infallible, meets Popper's objection, cited above, by remaining tentative, allowing for possible alterations of conduct as a result of the self-prediction itself seems possible and compatible with determinism.' (Berlin 1980, 187)

viii Kant considers, 'I entitle the world a moral world, in so far as it may be in accordance with all moral laws; and this is what by means of the freedom of the rational being it can be, and what according to the necessary laws of morality it ought to be.' (Kant 1929, 637)

\section{Bibliography}

Beck Lewis White, 1988, Kant Selections, London, New York: AScriber/Macmillan Book. Berlin Isaiah, 1980, Concepts and Categories, Oxford, Toronto, Melbourne: Oxford University Press.

Kant Immanuel, 1972, The Moral Law, The Groundwork of Metaphysic of Morals, Paton, H J (trans), London: Hutchinson University Library.

Kant Immanuel, 1996, The Metaphysics of Morals. Vol.154. New York: Cambridge University Press

Kant Immanuel, 1960, Religion Within the Limits of Reason Alone, Theodore Greene and Hoyt Hudson (eds), New York: Harper \& Row.

Kant Immanuel, 1974, Anthropology from a Pragmatic Point of View, Mary J Gregor, the Hague: Martinus Jihoff.

Kant Immanuel, 1988, Idea for a Universal History from a Cosmopolitian Point of View, in Kant's Selection, Lewis Beck (ed.), London, New York: Ascriber/Macmillan Book.

Kant Immanuel, 1929, Critique of Pure Reason, Norman Kemp Smith (trans.), London: Macmillan

Kant Immanuel, 2009, An Answer to the Question: 'What is Enlightenment?', H.B. Nisbet (trans.), London: Penguin Books

Korsgaard Christine, 2012, Creating the Kingdom of Ends, Cambridge: Cambridge University Press.

Papineau David, 2004, Philosophy the illustrated guide to understanding and using philosophy today, London: Duncan Bird Publishers.

Reiss Hans, 1971, 'Introduction', in Kant's Political Writings (ed.), Cambridge:

Cambridge University Press.

Russell Bertrand, 1995, History of Western Philosophy, London: Routledge

Strawson Peter F, 1966, The Bounds of Sense: An Essay on Kant's Critique of Pure

Reason, London: Routledge. 